\title{
MAPPING FLOOD-RELATED HAZARDS IN KARST USING THE KARSYS APPROACH: APPLICATION TO THE BEUCHIRE-CREUGENAT KARST SYSTEM (JU, SWITZERLAND)
}

\author{
Jonathan Vouillamoz, Arnauld Malard, Eric Weber, Pierre-Yves Jeannin \\ Swiss Institute for Speleology and Karst Studies, Rue de la Serre 68, CH-2301, La Chaux-de-Fonds, \\ info@isska.ch \\ Gabrielle Schwab Rouge \\ BG Ingénieurs Conseils SA Avenue de Cour 61, CH-1007, Lausanne, Gabrielle.SCHWABROUGE@bg-21.com
}

\begin{abstract}
The city of Porrentruy (JU, Switzerland) is vulnerable to flooding from karst water draining the system of the Beuchire-Creugenat. Major flood events in 1804 and 1901 led to heavy damages throughout the city and its vicinity. Furthermore small-scale flood events have been recorded five times in the last 30 years - each resulting in substantial costs.
\end{abstract}

The Beuchire-Creugenat karst system is characterized by a perennial outlet (the Beuchire spring) and several overflow outlets (among which the Creugenat temporary outflow is the most significant one) where the discharge rate often exceeds $15 \mathrm{~m}^{3} / \mathrm{s}$. The ratio between rainfall intensity and discharge rate of the overflow springs is not closely correlated. Therefore, the discharge rates and the conditions at which a certain overflow becomes active could not be assessed without a comprehensive understanding of the karst system behavior. Thus, the establishment of effective flood risk management measures remains significant challenge.

In order to assess similar flood events and to determine the most flooding vulnerable areas, the KARSYS approach has been applied to the Beuchire-Creugenat karst system. A detailed geological 3D model of the study area has been built in order to reproduce the aquifer base geometry, the extension of its expected saturated part(s) and the position of the main vadose flowpaths "drainage axes". This approach enabled the catchment area delineation by combination of subterraneous drainage axes. The comparison of the discharge time series of the main springs and the relevant rainfalls ( $\sim 10$-year series) provides sufficient implications for understanding and consequent reproducing of threshold functionality of the karst system exposed to flooding due to rainfall events. A relationship could be established between rainfall intensity/frequency (return period) and the corresponding elevation of the groundwater level within the karst conduits (or respectively, the relevant spring discharge rates). The known overflow springs have been added in the 3D model. The areas where (and when) karst groundwater is expected to reach the ground surface during extreme high-water events could be identified as potential overflow springs. Such draining sensitive areas have been delineated and mapped according to the calculated return period of multiannual, 30- and 300years flood events and the relevant maximum discharge rates at the main outlets have been assessed.

\section{Introduction}

Flood events in the Swiss Jura Mountains are dampened/ enhanced by karst overflows. The flood event of August, $1^{\text {st }} 1804$ in Porrentruy (JU) is a the largest known event of a flashy karst inundation (Prudhomme 1804).

Associated discharges reaching $100 \mathrm{~m}^{3} / \mathrm{s}$ have been reported - four or five times larger than big flood amount recorded for this karst system. Similar events were recorded in 1901 and 1910 (Figure 2). In addition to these events smaller - but still extreme events - occurred five times in the last 30 years (BG 2011). The most recent well documented flood event occurred on August $9^{\text {th }}, 2007$. The Creugenat overflow peak discharge approached $20 \mathrm{~m}^{3} / \mathrm{s}$.

The local authority (administration of the Jura canton) has to plan protective measures to diminish the potential damages from flooding to maximum extent possible. The understanding and prediction of such extreme situation 
is then required for assessing the probable occurrence and the intensity of such flood events, in order to manage areas threatened by flooding.

Two local civil engineer offices and the Swiss Institute for Speleology and Karst Studies (SISKA) - as a karst specialized institution - were asked to provide a model for the study region. The assessment was conducted applying the KARSYS approach (Jeannin et al. 2012) expanded with some hydraulic considerations. The aim was:

- To understand the significant characteristics of the groundwater flow routes and the position of the karst water table for various recharge scenarios. Recharge events with return periods ranging between 30- and 300- years were considered.

- To determine and map areas which are the most vulnerable to flooding assessed by the potential overflows of karst groundwater and to assess the related discharges at the outlets and - in a next work - within the subterraneous flowpaths.

The locations where karst groundwater is expected to reach the most forward ground surface are the most vulnerable to flooding. Having assessed the respective catchment areas of the underground tributaries, discharge rates can be assumed within the limitations of the project.

\section{Context}

The geological context refers to the Tabular Jura which is slightly folded and intersected by numerous strike faults (Kovács 2003, Sommaruga 1997). The Beuchire perennial karst spring emerges in the center of Porrentruy (see Figure 1) at an elevation of $423 \mathrm{~m}$ a.s.l. (meters above sea level). Its mean annual discharge is $800 \mathrm{~L} / \mathrm{s}$.

The spring reaches $1600 \mathrm{~L} / \mathrm{s}$ at high water flow and may discharge more than $3 \mathrm{~m}^{3} / \mathrm{s}$ during a flood event. Groundwater flow moves through the Malm aquifer which is composed of alternating units of Upper Jurassic limestone and thin layers of marls. The Malm aquifer is underlied by a thick marl formation (Astartes marls, Laubscher 1963). This aquifer reveals to be the most karstified one in the region. Although the underlying marls are qualified as impervious, the Malm's aquifer water exchanges with the lower aquifer are highly likely through discontinuities in the marls.

Upstream of the Beuchire spring, the Creugenat temporary outflow (see Figure 3) emerges at 451

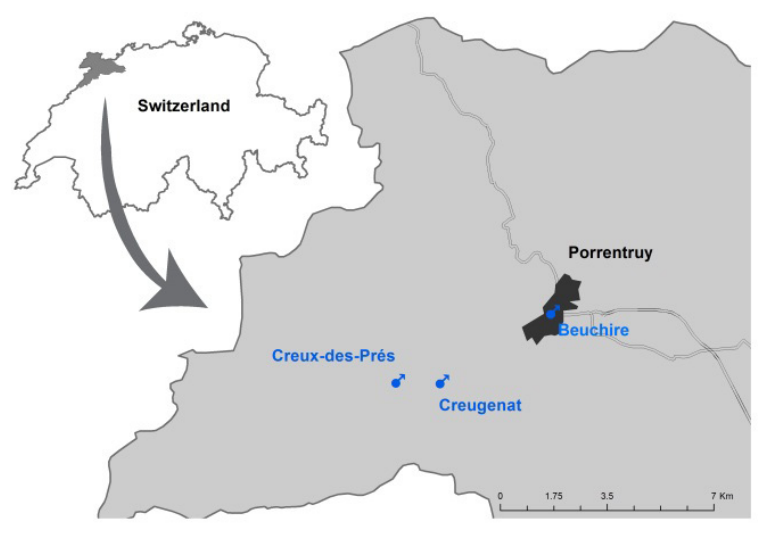

Figure 1.The Beuchire karst spring is located in the city of Porrentruy (JU) in Northwest Switzerland.

$\mathrm{m}$ a.s.l. It becomes active only at high water stage. The global discharges in the city of Porrentruy may reach a maximum close to $30 \mathrm{~m}^{3} / \mathrm{s}$ (Grétillat 1996). Further upstream, at an elevation of $465 \mathrm{~m}$ a.s.1., lies the estavelle of Creux-des-Prés which functions as a second temporary outlet of the system and becomes active only during very high water stage (see Figure 4). The discharge series of the Beuchire spring and pressure series of the Creugenat temporary outflow have been measured at hourly time steps, respectively between 1998 to 2004 and 1998 to 2008. In addition to these three main springs, a series of minor temporary outlets do exist. Unfortunately they are badly documented due to infrequent activity (Les sources, Libecourt, etc.).

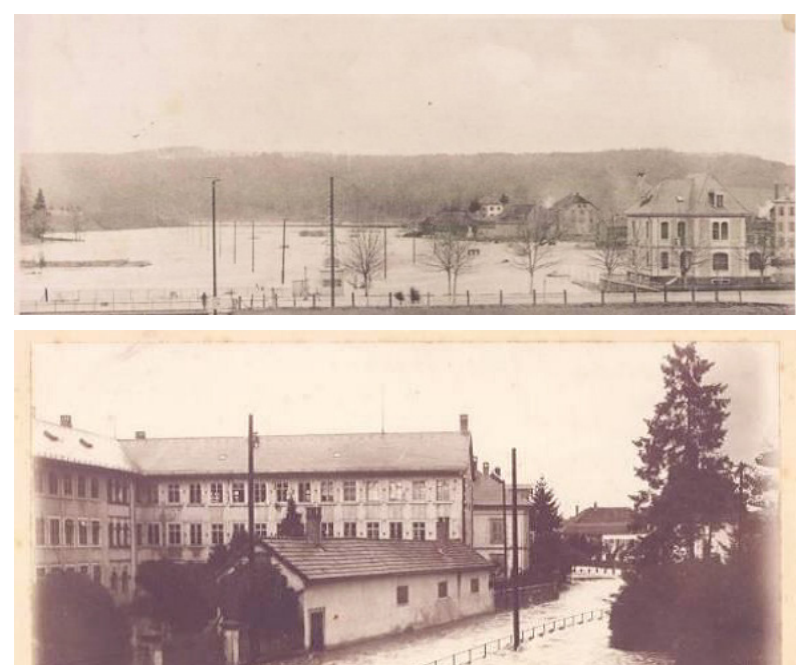

Figure 2. The flood event of 1910 in Porrentruy. Inundation is the result of extreme karst aquifer discharge through the Creugenat (Archives de la Bourgeoisie de Porrentruy, JU). 


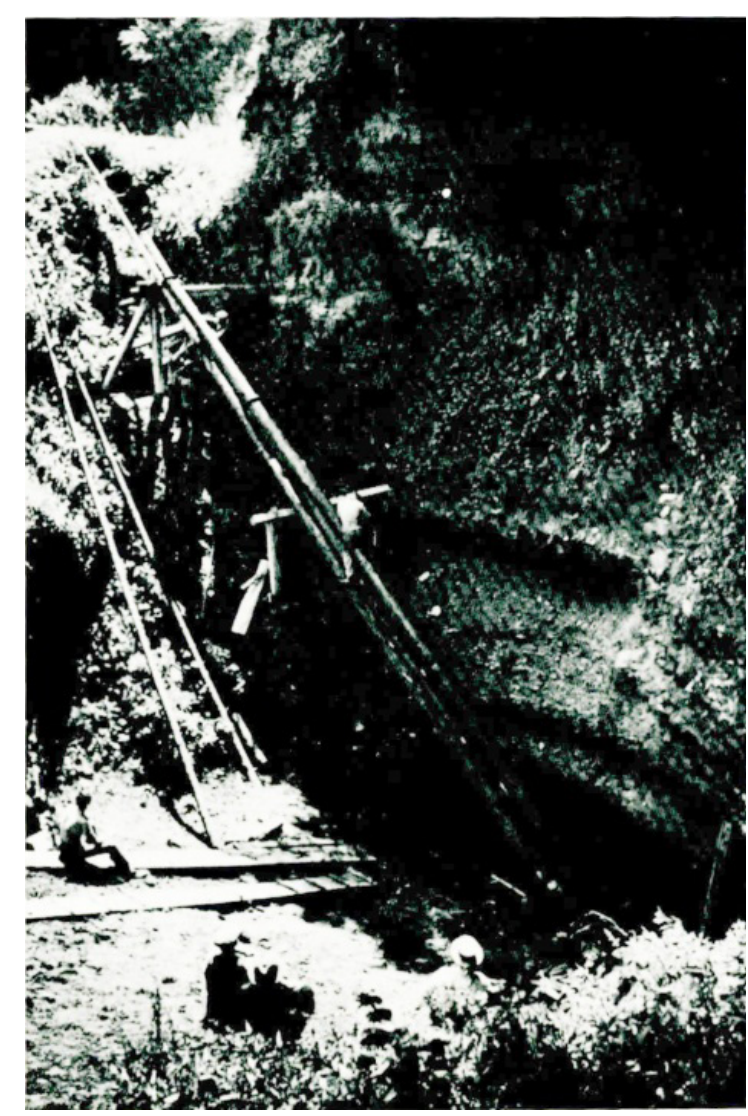

Figure 3. The Creugenat overflow in 1934. First pumping test to dry up the siphon (picture A. Perronne).

Although the Beuchire spring and the Creugenat overflow have been fairly studied (Bouvier 2006; Grétillat 1996, Hessenauer and Meury 2002,Kovács and Jeannin 2003, Lièvre 1915, Lièvre 1940, Schweizer 1970, Monbaron 1975, etc.) available data remained limited and some questions did not find a clear solution. None of these studies describes in details the potential catchment boundaries and their possible changes in relation to the water stage. In this context the KARSYS approach (Jeannin et al. 2012)

Figure 4. SW-NE profile of the Beuchire catchment and projection of the overflow outlets. The real distance between the Beuchire spring and the Creugenat temporary overflow is 4,3 km. The Creugenat overflow and the Creux-des-Prés temporary overflow are $1.45 \mathrm{~km}$ appart. was applied to estimate the geometry of the aquifer(s) boundaries, to delineate groundwater body(ies), and to assess the functioning of the Beuchire spring and the Creugenat overflow.

This approach was assessed for low, medium, high and extremely high water conditions.

\section{A 3D model to assess the aquifer geometry}

In order to assess the geometry of the aquifer, a 3D geological model focusing on the aquifer basement (i.e. Astartes marls) was established for the area of interest $(14 \mathrm{~km}$ by $9 \mathrm{~km}$ ) at a scale close to $1 / 25,000$ (see Figure 5) to meet the requirements of a pragmatic issue. This was possible thanks to an extensive compilation of all existing data relative to geological information (borehole logs, maps, cross sections, tunnel profiles, dye tracer tests results, etc.) and the previous work of Kovács 2003, which provided a strong basis of documentation.

Once the geological model has been established and the data checked, the hydrological features have been implemented within the 3D model. These features consist of major perennial springs as well as minor temporary ones. Then, the extension of the saturated part of the aquifer was assessed by following the KARSYS approach.

This approach assumes that at low water stage, the top of the saturated part of a karst aquifer is close to horizontal and can be represented within the model by a horizontal plane at the main perennial spring elevation (the Beuchire spring in the present case). The portion of the aquifer located underneath that horizontal plane should be close to the volume extension of the karst phreatic zone. sw

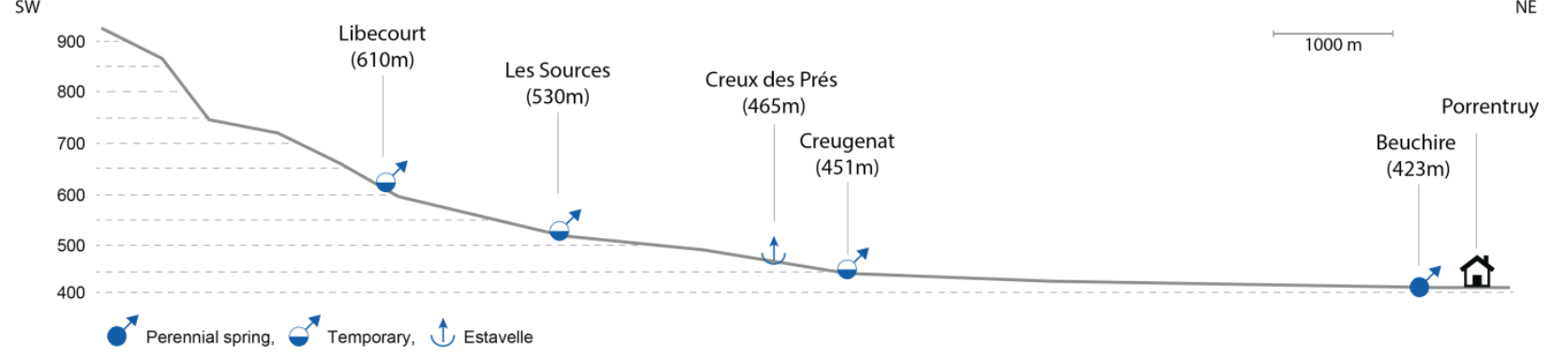




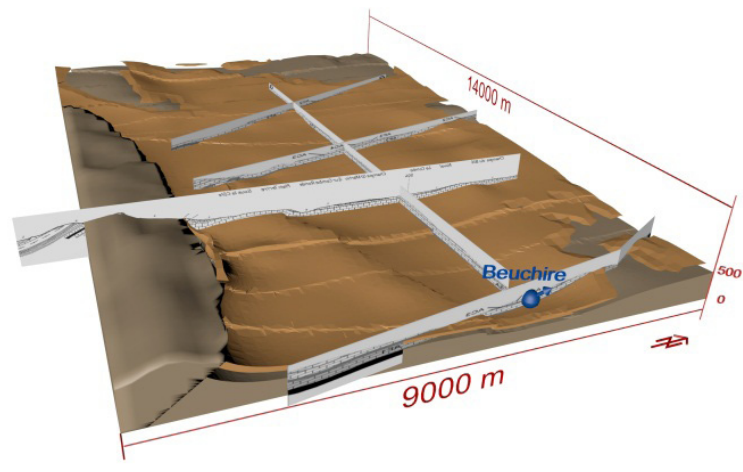

Figure 5. Illustration of the 3D geological model of the aquifer basement from the Beuchire karst system intersected by geological cross-sections. This was modeled using GeoModeller ${ }^{\circledR}$ (Intrepid Geophysic). The main spring is on the front of the model.

This process was applied to the model and gives the following results (Figure 6).

The process identified two unconfined groundwater bodies (GWB A and B) separated by a geological threshold which top elevation is at $440 \mathrm{~m}$ a.s.l. This fact also predetermined the volume extension and surface areal extension of each GWB, $21 \mathrm{~km}^{2}$ (A) and $6 \mathrm{~km}^{2}$ (B) and taking into account the assumed limestone porosity ( $\sim 1 \%$ in a first approximation) the water content could be estimated; respectively as $6.4 \mathrm{Mm}^{3}$ and $2.9 \mathrm{Mm}^{3}$ at the low water stage.

Knowing the location and volume extension of the saturated parts of the aquifer, the catchment area feeding each of these groundwater bodies could be delineated. Then, following the shape of the

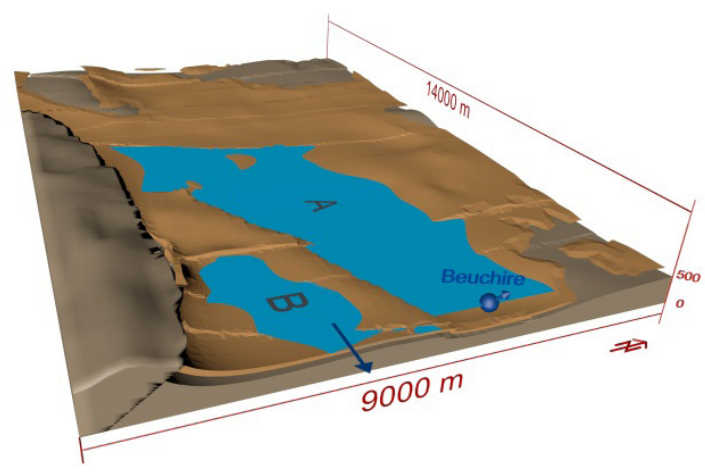

Figure 6. Model identification of two main groundwater bodies (GWB), A = Beuchire GWB (elevation $423 \mathrm{~m}$ a.s.l), $B=$ Bonnefontaine GWB (elevation $438 \mathrm{~m}$ a.s.l). aquiclude topography, sub-catchments and their respective "drainage axes" were rendered. Drainage axes are recognized as vadose ones if they are located above the saturated zones. They are assumed to be developed at the bottom of the aquifer along the dip of the basement. Phreatic passages located within the saturated zones are "drainage axes" linking input points into the phreatic zone to the main drainage axis linking of the Creugenat temporary outflow and the Beuchire spring. Phreatic flowpaths are mainly horizontal and a priori follow the shortest hydraulic distance to the outlet(s).

The model result for low water stage is presented in Figure 7.

The total groundwater catchment area in low water situations is thus estimated at about $79 \mathrm{~km}^{2}$. GWB A flow is driven toward the Beuchire spring and GWB B flow is drained toward the Bonnefontaine spring, which is not visible in the figures for this paper.

\section{Assessing the system at high water stage (hydraulic gradients within the conduits)}

In the next step, the hydrology of the system is assessed for high water conditions, i.e. when overflow springs (Creugenat and Creux-des-Prés) successively become active according to the rise of the groundwater head in the conduits.

The discharge data from the Beuchire spring are compared with the head data recorded at the Creugenat temporary overflow (see Figure 8).

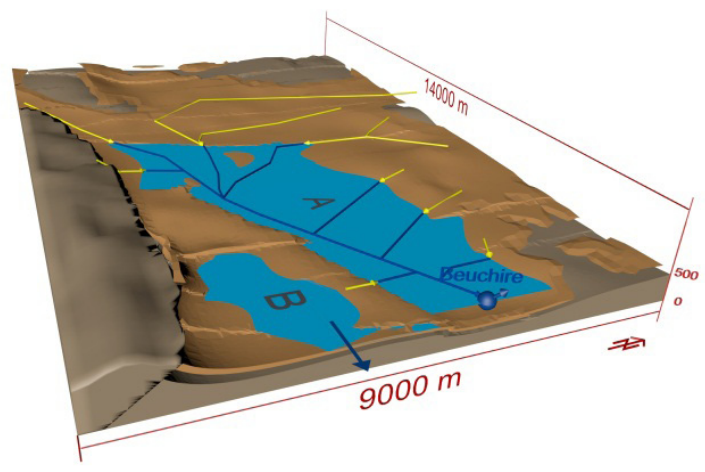

Figure 7. Model identification of the main underground vadose (yellow) and phreatic (blue) flowpaths of the Beuchire-Creugenat karst system at low water stage. 
The graphic indicates that:

- As the Beuchire spring discharge remains lower than $700 \mathrm{~L} / \mathrm{s}$, the water level at the Creugenat overflow does not react ( $\sim 438 \mathrm{~m}$ a.s.l). This indicates that both systems are disconnected by a threshold (a) situated at this elevation.

- As the discharge exceeds $700 \mathrm{~L} / \mathrm{s}$ the water level progressively rises up and shows a threshold (b) at $443 \mathrm{~m}$ a.s.1 corresponding to a discharge of $1,450 \mathrm{~L} / \mathrm{s}$

- As the discharge exceeds $1,500 \mathrm{~L} / \mathrm{s}$ the water level at the Creugenat rises up a second time until it reaches the output elevation (c) at $451 \mathrm{~m}$ a.s.1 corresponding to a discharge of $2,250 \mathrm{~L} / \mathrm{s}$.

Contrary to previous studies (Grétillat 1998, Hessenauer and Meury 2002) which considered threshold (b) as a first activation of the Creugenat overflow, this analysis indicates that the Creugenat becomes active only when the Beuchire spring discharge exceeds $2,250 \mathrm{~L} / \mathrm{s}$. Then threshold (b) indicates that an intermediate overflow (or large storage) must exist in between (at around $443 \mathrm{~m}$ a.s.1). This could be a karst conduit or an outlet to the ground surface.

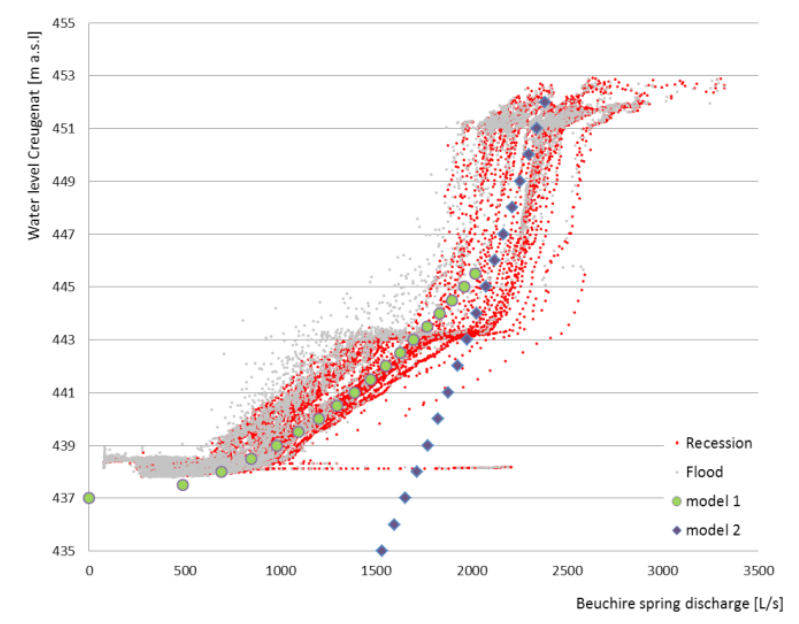

Figure 8. Comparison of the hourly pressure data recorded at the Creugenat overflow and the hourly discharge values of the Beuchire spring during flood (grey) and recession (red) events (2002-2004). Model 1 simulates a threshold discharge at an elevation of $437 \mathrm{~m}$ a.s.l at a suggested distance of $7,300 \mathrm{~m}$ downstream from the Creugenat. Model 2 simulates an ideal function of the spring discharge using a $k^{*} S$ of $28 \mathrm{~m}^{3} / \mathrm{s}$ (conduits diameter of $\sim 2.7 \mathrm{~m}$ ) and a straight distance of 4,000 m.
Assuming that the flows to Beuchire spring may follow the usual head-loss laws in pipes (Darcy-Weisbach type), the relation can be simulated using the following equation:

$$
Q=k^{\prime} S * \sqrt{\frac{d H}{d L}}
$$

With $\mathrm{Q}\left[\mathrm{m}^{3} / \mathrm{s}\right], \mathrm{k}^{*} \mathrm{~S}=\mathrm{f}\left(\right.$ section $\left.\mathrm{m}^{2}\right)\left[\mathrm{m}^{3} / \mathrm{s}\right], \mathrm{dH} / \mathrm{dL}=$ hydraulic gradient $[\mathrm{m} / \mathrm{m}]$. Application of this law is plotted on the chart (models $1 \& 2$, Figure 8).

Model 1 suggests that the hydraulic connection between the Beuchire spring and the Creugenat overflow is active when the water elevation in the conduits ranges from 438 to $443 \mathrm{~m}$ a.s.l. Below this value the system follows a head-loss equation. However, this model cannot explain the observed relationship of the water level between 443 and $451 \mathrm{~m}$ a.s.l.

Therefore, model 2 depicts a hypothetical outlet at threshold (a) downstream from the Creugenat overflowi.e. at an elevation of $443 \mathrm{~m}$ a.s.l. The head-loss equation is valid for an outlet located at a distance of 4,000 $\mathrm{m}$ and with a $\mathrm{k}^{\prime} \mathrm{S}$ of $28 \mathrm{~m}^{3} / \mathrm{s}$ (considering an average conduit diameter of $2.7 \mathrm{~m}$ ) to reproduce the observed trend.

Previous observations led to the hydraulic schemes of the karst system presented in Figure 9 that depends on the groundwater level elevation. This provides a set of hydraulic gradients which can be implemented in the 3D model at various high water flow conditions. One result is displayed on Figure 10 where the gradients correspond to a usual overflow of the Creugenat (average annual flood event) at high water stage. Upstream of the Beuchire spring the hydraulic gradient strongly increases until it reaches the Creugenat overflow (the slope of the gradient is close to $0.7 \%$ ). If the water level still increases the Creugenat overflow becomes active and the gradient does not rise significantly ahead. In Figure 13 areas that are susceptible to flooding during such events are mapped in yellow.

Similar scenarios could be established for two larger flood events: the 30- and the 300- years flood events. The August 2007 flood event, defined as a 30 years event (by analysis of the IDF curves, BG 2012) is characterized by the Creux-des-Prés overflow. Between the Beuchire spring and the Creugenat overflow the hydraulic gradient remains comparable to the value encountered above 

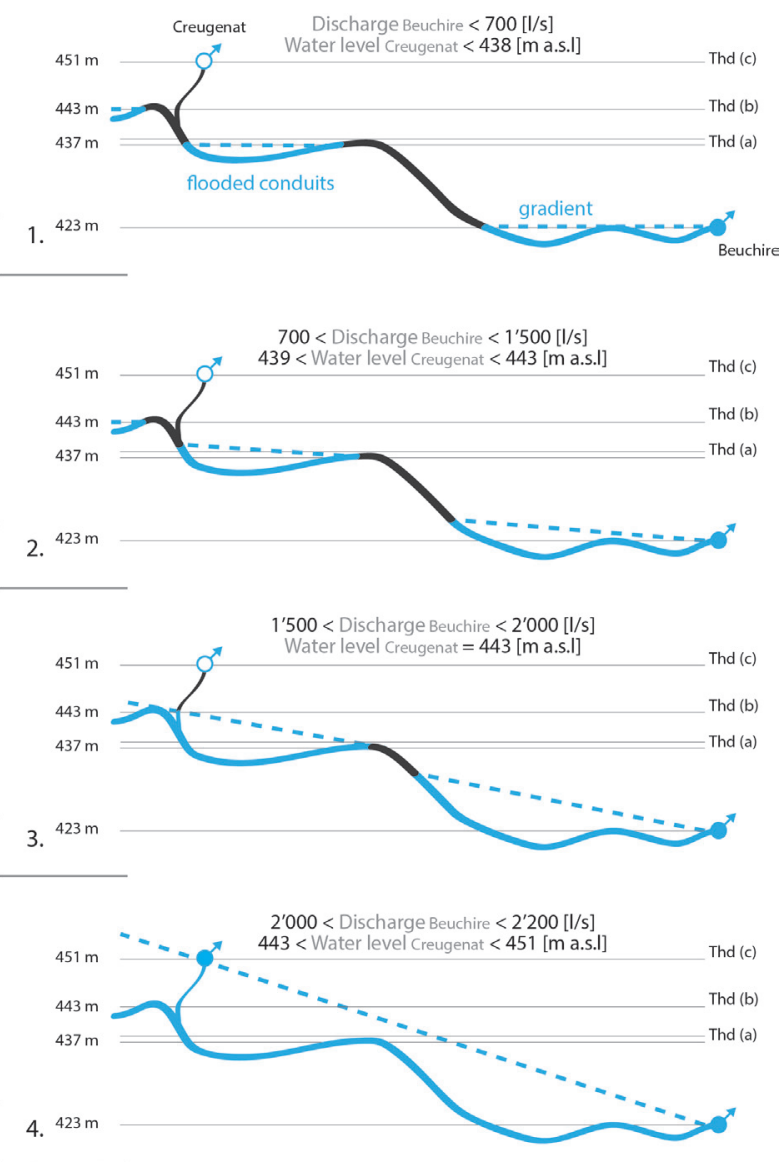

Figure 9. Sequential evolution of the hydraulic gradient within the Beuchire-Creugenat karst system (i.e. the conduits) for an average annual flood event reaching the Creugenat overflow. The profile of the conduits is here supposed. Processes are the following:

1. The groundwater level at the Creugenat overflow is independent of the Beuchire spring discharge oscillations;

2. The water level at the Creugenat overflow is controlled by the threshold (a);

3. At $443 \mathrm{~m}$ a.s.l. the activation of an additional conduit (or a perched spring) show a lag in the water level elevation rise at the Creugenat overflow;

4. The rise of the groundwater level at the Creugenat overflow depends on the Beuchire spring discharge. At $451 \mathrm{~m}$ a.s.I the Creugenat overflow is now flowing!

( $\sim .7 \%)$. Upstream of the Creugenat overflow, the hydraulic gradient of the groundwater flow in the conduits is here fixed by Le-Creux-des-Prés outlet and by the bottom of the valley (several outlets were active during the 2007 flood events providing some arguments to fix the gradient): its slope is approximately $1 \%$ extending the groundwater bodies as pictured in Figure 11. The areas which are vulnerable to flooding when such type of flood event occurs are filled in orange in Figure 13.

For a 300-year flood event (as the flooding in 1804) the hydraulic gradient within the conduits does not change between the Beuchire spring and the Creugenat overflow $(0.7 \%)$ and between the Creugenat and the Creux-des-Prés overflows $(\sim 1 \%)$. Upstream of the Creux-des-Prés we allocated the gradient on the basis of the more elevated outlets (higher than $500 \mathrm{~m}$ a.s.l) and the shape of the versants. The gradient is therefore approximately $1.5 \%$. Surfaces that are here vulnerable to flooding are the more extended ones (labeled in red in Figure 13).

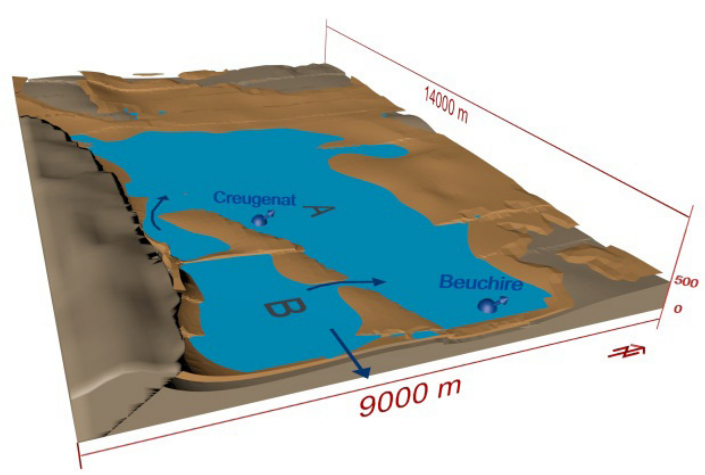

Figure 10. Model prediction of the extension of groundwater bodies (GWB) A and B during a flood event reaching the Creugenat overflow (= multiannual occurrence =case 4 in Figure 9). Water from GWB $B$ overflows over two passes and contributes to the discharge of the Beuchire spring.

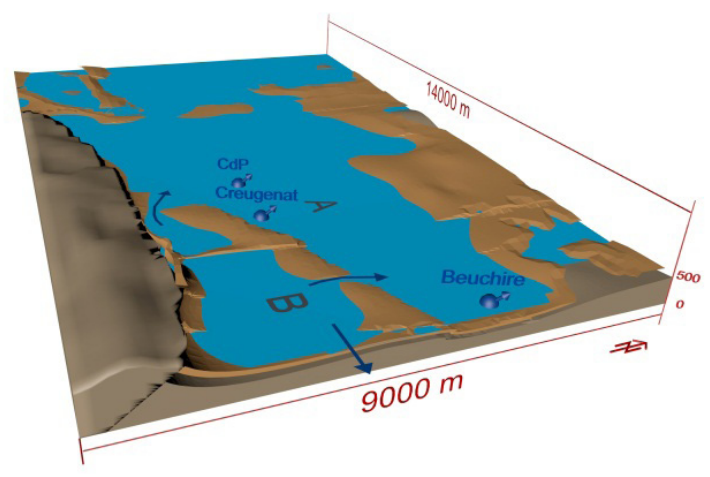

Figure 11. Model prediction of the saturated groundwater bodies extension in the BeuchireCreugenat karst system during a flood event reaching the Creux-des-Prés overflow ( $\sim 30$-year flood event). 


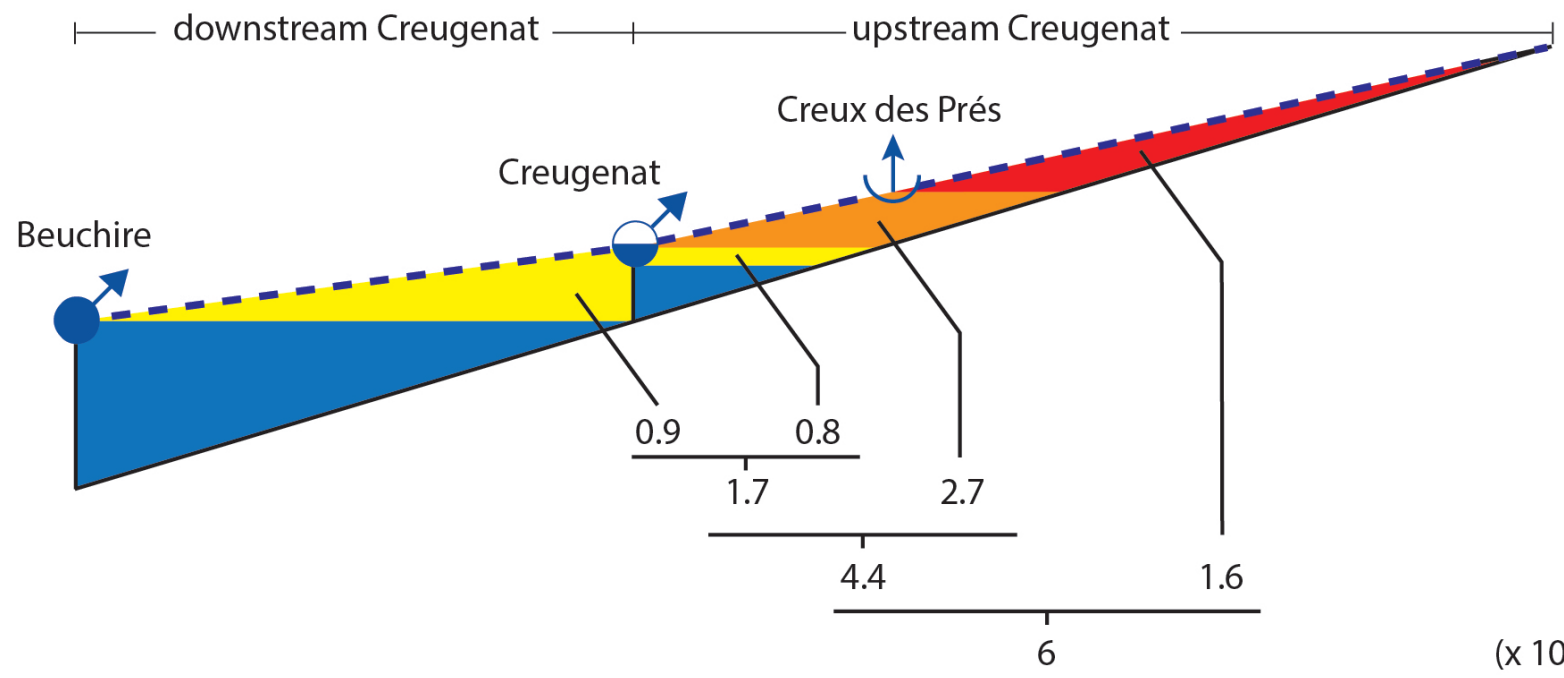

$\left(\mathrm{x} 10^{6} \mathrm{~m}^{3}\right)$

Figure 12. Model predicted storage in the aquifer (i.e. the karst conduits) and its development due to groundwater increase within the karst system for the respective flood events (average annual, 30-year flood events and 300-year flood events). The associated volumes refer to water potentially involved in the floods (1.7 $\mathrm{Mm}^{3}$ for an average annual flood event, $4.4 \mathrm{Mm}^{3}$ for a 30-year flood event and more than $6 \mathrm{Mm}^{3}$ for a 300-year flood event).

In addition to these gradients some further temporary springs were observed previously in the field and reported by Bouvier 2006. They were used as controls for the prediction of potential outlets based in the 3D model.

Considering the respective values of the hydraulic gradients during these events, it is possible to estimate the associated volume of groundwater involved in the floods (or at least which should flow within the system). This implies to know or at least estimate a value of efficient porosity (i.e. density of conduits / volume of flooded aquifers) which could be taken as a first approximation about $0,5 \%$ (in the swiss Jura, according to Bauer et al. 1980, Burger and Pasquier 1984). This value may be refined in the further development of the project.

\section{Mapping the flooded areas}

According to the previous model results it is possible to map surface areas which could be affected by the potential flood events. The results for the Beuchire-Creugenat catchment are displayed in Figure 13. The next step in flooding hazard characterization is the expected drainage
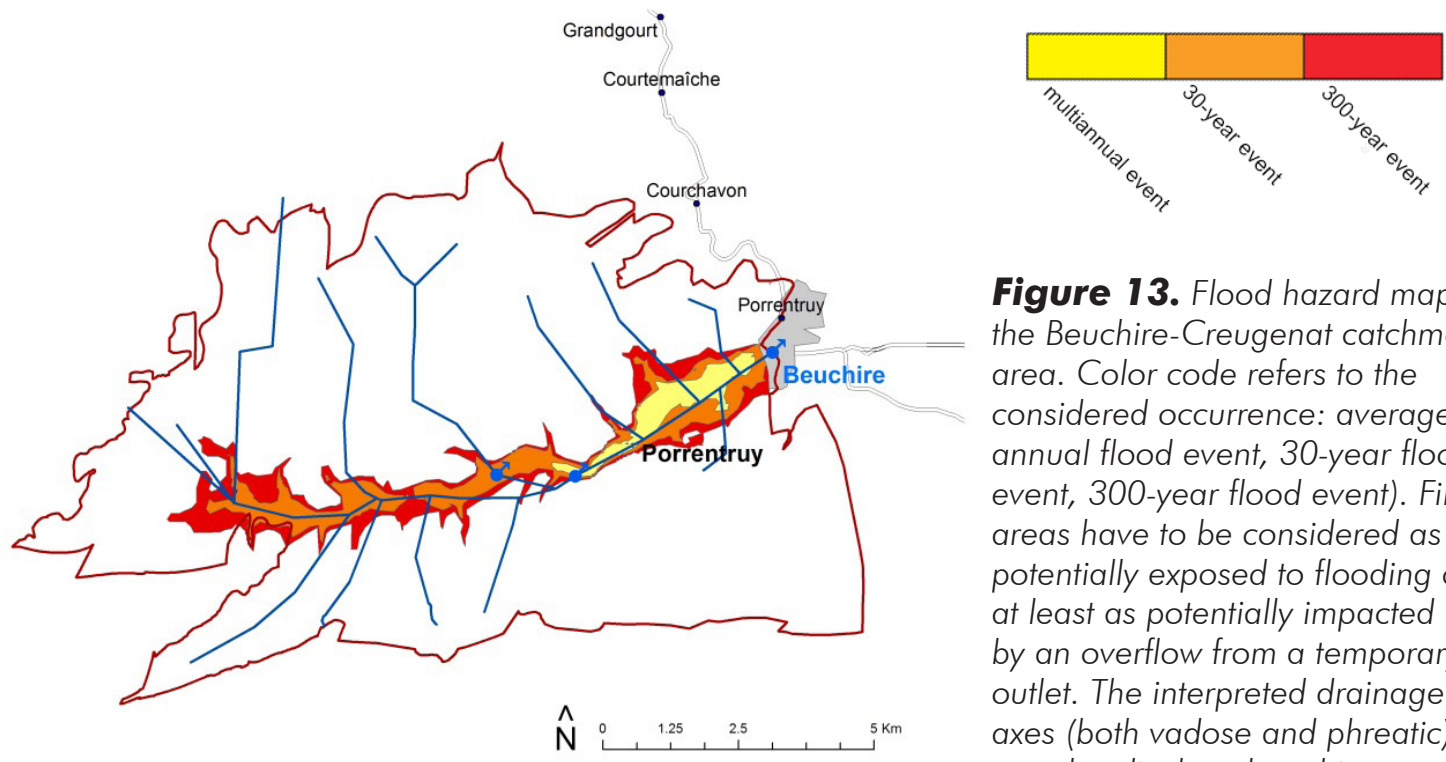

Figure 13. Flood hazard map of the Beuchire-Creugenat catchment area. Color code refers to the considered occurrence: average annual flood event, 30-year flood event, 300-year flood event). Filled areas have to be considered as potentially exposed to flooding or at least as potentially impacted by an overflow from a temporary outlet. The interpreted drainage axes (both vadose and phreatic) are also displayed on this map. 
axes discharge rates assessment for each type of flood event. This is possible once the catchments of these have been clearly delineated as well as their respective recharges. This assessment will be conducted in the second part of the project by the establishment and the use of a hydraulic model. In the present paper only the maximum discharge of the respective outlets (permanent and temporary ones) was assessed for a average annual flood event and a 30 years flood event. Such models are useful for designing future construction or hydraulic works.

\section{Maximum expected discharges at the outlets}

Discharge of springs usually increases as the level of the groundwater increases within the system until one overflow spring becomes active. Then, even if the groundwater level still rises in the conduit, the discharge of the lower spring does not increase significantly. Based on that principle, it is possible to estimate the maximum expected discharges at the Beuchire spring and the Creugenat overflow.

Regarding the Beuchire spring, the maximum discharge is limited by the overflowing of the Creugenat outlet (Figure 8). Even if the groundwater level in the karst system still increases the Beuchire spring cannot discharge more than $3,5 \mathrm{~m}^{3} / \mathrm{s}$.

The maximum discharge rate at the Creugenat outlet can be estimated from the discharge of the stream in the city of Porrentruy as soon as the Creux-des-Prés overflow becomes active. Comparing the last 2007 flood event with a 30 years flood event and knowing the moment when the Creux-des-Prés overflow discharged - it was estimated that the maximum discharge rate at the Creugenat overflow is about $18 \mathrm{~m}^{3} / \mathrm{s}$.

\section{Discussion}

In June 2012 a collapse appeared in the middle of a road, on a straight line between the Beuchire spring and the Creugenat overflow (Figure 14, ISSKA 2012). The pit located at an elevation of $443 \mathrm{~m}$ a.s.1 - reached the depth of $8 \mathrm{~m}$ and at that time its bottom was dry. This collapse gave the SISKA the opportunity to install a pressure sensor with the aim to survey an eventual presence and oscillations of the groundwater within the pit. The recorded data (only few weeks available) show periodic rises of the groundwater with a maximal elevation of $438.6 \mathrm{~m}$ a.sl ( 4,5 $\mathrm{m}$ below the surface) that led to a
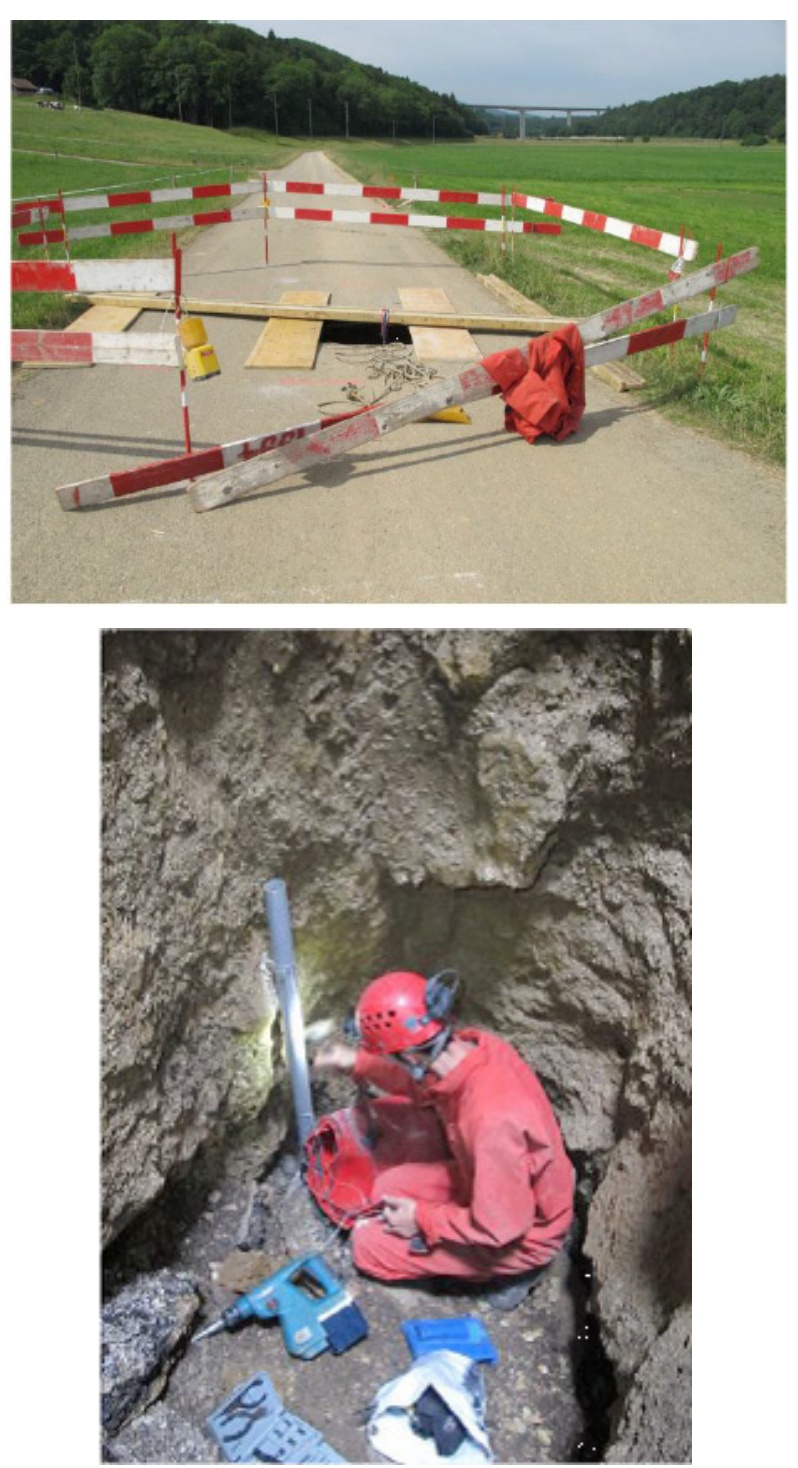

Figure 14. The new collapse of the community of Courtedoux gave access to a $8 \mathrm{~m}$ deep pit. The bottom of the pit was monitored with a pressure sensor. The recent data allowed validation and improvement of the Beuchire-Creugenat karst system model functionality.

deepening of the collapse. The recorded oscillations of the groundwater are consistent with the previous interpretation related on Figure 9.

In addition to this flood event, new piezometric data were collected from a borehole (POR3) located in the vicinity of the Creugenat overflow. First comparison of these data with the recorded oscillations of the Creugenat overflow provides new calibration elements that improve the model functionality. Currently, a series of simulations are being conducted using the actual release of SWMM 
(Storm Water Model Management, Rossman 2004) to approach the karst conduits and to fix the thresholds and the related storage within the aquifer.

The identification of the main drainage axes will lead to the delineation of sub-catchments areas within the system catchment. When they are defined their respective recharges will be assessed and extrapolated to estimate the maximum discharges which could be expected within the conduits. These simulations are expected to produce relevant results that will improve the modeling of the flood hazards in the region of the Beuchire-Creugenat karst system. They will also bring quantitative elements to design future construction and hydraulic works.

\section{Conclusion}

The characterization of the flood hazard in the vicinity of the city of Porrentruy - vulnerable to flooding by the Beuchire-Creugenat karst system discharge- was conducted by applying the KARSYS approach. A 3D geological model depicting the aquifer basement has been established and progressively improved with field data and literature documentation. By following the hydraulic principles in karst hydrology, it was possible to sketch the vadose and the phreatic zones as well as the main suspected flowpaths. The catchment area of the system has been delineated and divided in basin-units aiming distinguishing their recharge contribution at the next stages of the study. By using the available discharge data of the Beuchire spring and head measurements of the Creugenat overflow it has been possible to determine a thresholds functioning of the system and to approach the geometry of the groundwater hydraulic within the conduits in the high water stage and to delineate where water is susceptible to reach the ground surface and to enhance the risk of inundation. Areas on ground surface may be affected by flooding depending on the occurrence of the mapped considered events (average annual flood event, 30-year flood event, 300-year flood event). Furthermore successive activation of the outlets and their associated discharges are now predictable.

Recent integration of piezometric data from a borehole in the vicinity of the main temporary outlet (Creugenat) and the more recent instrumentation and observations in the collapse at Courtedoux (which appeared in June 2012) brought new indicators to control and improve the established model. Current simulations using SWMM and based on these new data may provide new elements in conduit geometry characterization and to improve the hydrological model. The last could be applied in further hydraulic planning, especially in estimating the groundwater discharge contribution for each basin unit. Applications to assist the design of future construction and hydraulic works could also be envisaged.

\section{Acknowledgments}

The study of the characterization and prediction of the flood hazards in the vicinity of the city of Porrentruy was in collaboration with two local offices: Buchs \& Plumey (Porrentruy) and BG (Lausanne). Thanks to the administration of the Jura Canton for their financial support. The authors are thankful to MFR (Delémont) and caving clubs for providing information and data.

\section{References}

BG. 2011. Carte des dangers - Haute Ajoie et Mont Terri Sud - Données historiques, unpubl. rep. BG Ingénieurs Conseils.

BG. 2012. Etude de danger inondation - Vallée de la Haute-Ajoie, Rocourt et Grandfontaine, unpubl. rep. BG Ingénieurs Conseils.

Bauer F, Benischke R, Bub F, Burger A, Dombrowski $\mathrm{H}$ et al. 1980. Karsthydrologische Untersuchungen mit natürlichen und künstlichen Tracern im Neuenburger Jura .Schweiz.. Steirische Beiträge zur Hydrogeologie 32: 5-100.

Bouvier JC .2006. Hydrographie et géomorphologie karstique de la zone frontalière du département du Doubs .France. et du canton du Jura .Suisse.. "Gestion durable de l'environnement karstique" Actes de la réunion annuelle de la Société Suisse de Géomorphologie .SSGm. La-Chaux-de-Fonds, Suisse, 3-4 septembre 2004. p. 97-104.

Burger A, Pasquier F. 1984. Prospection et captage d'eau par forages dans la vallée de la Brévine .Jura Suisse. Hydrology of karstic terrains 1: 145-149 p.

Grétillat PA. 1996. Aquifères karstiques et poreux de l'Ajoie .JU, Suisse. Eléments pour la carte hydrogéologique au 1:25'000 .vol II. Notice explicative de la carte hydrogéologique $[\mathrm{PhD}$ dissertation]. Centre d'Hydrogéologie de l'Université de Neuchâtel, Suisse. 37 p.

Grétillat PA. 1998. Systèmes karstiques de l'Ajoie .Jura, Suisse. Eléments pour la carte hydrogéologique de l'Ajoie au 1:25'000 [PhD dissertation]. Centre d'Hydrogéologie de l'Université de Neuchâtel, Suisse. 219 p.

Hessenauer M, Meury P .2002. Estavelle du Creugenat, Jura. Stalactite 52(2): 41-50. 
ISSKA. 2012. Expertise hydrogéologique de l'effondrement de Courtedoux. Institut Suisse de Spéléologie et de Karstologie, La Chaux-de-Fonds, Suisse - note technique - mandant: Service des ponts et chaussées du canton du Jura. $5 \mathrm{p}$.

Jeannin PY, Eichenberger U, Sinreich M, Vouillamoz J, Malard A et al. 2012. KARSYS: a pragmatic approach to karst hydrogeological system conceptualisation. Assessment of groundwater reserves and resources in Switzerland. Environmental Earth Sciences. Available from: http://dx.doi.org/10.1007/s12665-012-1983-6.

Kovács A. 2003. Geometry and hydraulic parameters of karst aquifers: A hydrodynamic modeling approach $[\mathrm{PhD}$ dissertation]. Centre d'Hydrogéologie de l'Université de Neuchâtel, Suisse. 131 p.

Kovács A, Jeannin PY. 2003. Hydrogeological overview of the Bure plateau, Ajoie, Switzerland. Eclogae geol. Helv. 96: 367-379.

Laubscher HP. 1963. 1085 St-Ursanne. Geologischer Atlas der Schweiz 1/25 000. Erläuterungen 40: 27 p.

Lièvre L. 1915. Le problème hydrologique de la Haute Ajoie et le Creux-Genaz. Contribution à l'étude de la circulation souterraine en terrains calcaires. Actes de la Société Jurassienne d'Emulation. p. 75-111.

Lièvre L. 1940. Le karst jurassien: hydrologie de la haute-ajoie et découverte d'une rivière souterraine du jura bernois. Librairie le Jura S.A, Porrentruy.

Monbaron M. 1975. Contribution à l'étude des cluses du Jura septentrional [ $\mathrm{PhD}$ dissertation]. Université de Neuchâtel, Suisse. 208 p.

Prudhomme LM. 1804. Dictionnaire universel, géographique, statistique, historique et politique de la france. tome quatrième .p-saj. Baudouin, Paris.

Rossman LA. 2004. Storm water management model. user's manual version 5.0. United States Environmental Protection Agency.

Schweizer HU. 1970. Beiträge zur Hydrologie der Ajoie .Berner Jura. Beiträge zur Geologie der Schweiz 17: $223 \mathrm{p}$.

Sommaruga A. 1997. Geology of the central Jura and the Molasse Basin: new insight into an evaporite-based foreland fold and thrust belt [PhD dissertation]. Université de Neuchâtel, Suisse. 176 p. 